\title{
Fate and behavior of Chromium in mining-impacted paddy soils
}

\author{
EVELYNE ADJEI MENSAH, PHD ${ }^{1}$, ALEXIS GROLEAU ${ }^{1}$, \\ DIVYASREE PRABHAKARAN ${ }^{2}$, AMITH G. ANIL ${ }^{2}$, CÉCILE \\ QUANTIN $^{3}$, VIVIANA BOLANOS BENITEZ ${ }^{1}$, SAJEEV \\ KRISHNAN $^{2}$, VENI SUDARSAN ${ }^{2}$, PRAVEEN \\ RAMAMURTHY $^{2}$, SANKARAN SUBRAMANIAN ${ }^{2}$ AND \\ YANN SIVRY ${ }^{4}$ \\ ${ }^{1}$ Institut de Physique du Globe de Paris, Université de Paris \\ ${ }^{2}$ Indian Institute of Science \\ ${ }^{3}$ GEOPS, Université Paris-Saclay, CNRS \\ ${ }^{4}$ IPGP-CNRS UMR 7154
}

Presenting Author: evelyne.mensah@outlook.fr

Our goal is to determine to what extent $\mathrm{Cr}$ isotopic composition can help to understand $\mathrm{Cr}$ behavior and fate when released from mining areas to the surrounding paddy soils. We focus on the mining area of the Sukinda Valley (Orissa, India) which comprises $\sim 98 \%$ of India's chromium ore reserve. The activity produces huge amounts of tailings. Tailings are noneconomically viable materials stored outdoor. They are characterized by 80 and $15 \mathrm{wt} \%$ of hematite and chromite respectively. A selection of 3 uncontaminated paddy soils was used as reference. They are composed of 74 and $55 \mathrm{wt} \%$ of silica and hematite, respectively, and less than $2 \mathrm{wt} \%$ of chromite. Contaminated paddy soils picked up in the surrounding area of tailings displayed the same mineralogy with a chromite content that reaches up to $8 \mathrm{wt} \%$.

Batch experiments were performed to determine the leachability of chromium bearing phases from both the tailings and the reference soils. These later contain light $\mathrm{Cr}\left(\delta^{53} \mathrm{Cr}=\right.$ $-1.21+/-0.09 \%$ ) , but the corresponding leachates hardly reached $30 \mu \mathrm{g} / \mathrm{L}$ of $\mathrm{Cr}$ that is mostly trivalent and globally enriched in light isotopes ( $\delta^{53} \mathrm{Cr}$ up to $-0.8+/-0.07 \%$ ). Up to $2000 \mu \mathrm{g} / \mathrm{L}$ of $\mathrm{Cr}$ was leached from tailings as $\mathrm{Cr}(\mathrm{VI})$ after 18 hours. This $\mathrm{Cr}$ displays enrichment in heavy isotopes, with a $\delta^{53} \mathrm{Cr}$ values up to $0.13+/-0.09 \%$, whereas the bulk tailing is light $\left(\delta^{53} \mathrm{Cr}=-0.47+/-\right.$ $0.04 \%$ ). In the contaminated area downstream the tailings, the leachates of the two contaminated soils have opposite patterns. Bulk soils are both enriched in heavy isotopes $\left(\delta^{53} \mathrm{Cr}=\right.$ $1.84+/-0.43$ and $1.30+/-0.09 \%$ respectively). The first one releases $\mathrm{Cr}(\mathrm{VI})$ that is anomalously enriched in light isotopes $\left(\delta^{53} \mathrm{Cr}=-1.42+/-0.08 \%\right.$ ). This may be explained by the $\mathrm{Cr}$ reduction in the presence of dissolved $\mathrm{Fe}(\mathrm{II})$. While in the second one, $\mathrm{Cr}$ is mostly leached as $\mathrm{Cr}(\mathrm{III})$ with light $\delta^{53} \mathrm{Cr}$ signatures $\left(\delta^{53} \mathrm{Cr}=-1.98+/-0.08 \%\right.$ ) compared to the bulk.

The chromium transfer through paddy soils when irrigated with tailing leachate was then mimic using opened-flow columns, to help deciphering the impact of $\mathrm{Fe}$ and Mn oxides on $\mathrm{Cr}$ speciation and isotopic composition when transfer into the paddy soils from the tailing leachates. 